\title{
Women's involvement in Family Firms: \\ Progress and Challenges for Future Research
}

\section{Giovanna Campopiano*}

Witten Institute for Family Business - University of Witten/Herdecke

Alfred-Herrhausen-Strasse 50, 58448 Witten (Germany)

Phone: +49 (0)2302/926-535

E-mail: giovanna.campopiano@uni-wh.de

\author{
Alfredo De Massis*a \\ Free University of Bozen-Bolzano and Lancaster University \\ Faculty of Economics and Management \\ Universitätsplatz 1 - Piazza Università, 1 \\ 39100 Bozen-Bolzano \\ Phone: +390471013303 \\ E-mail: alfredo.demassis@unibz.it \\ and
}

Department of Entrepreneurship, Strategy \& Innovation, Lancaster University Management School (UK)

\section{Francesca Romana Rinaldi*}

Bocconi University

Via Bocconi, 8 Milan (Italy)

Phone: +390258366325

E-mail: francesca.rinaldi@unibocconi.it

\section{Salvatore Sciascia*}

IULM University

Via Carlo Bo, 1 Milan (Italy)

Phone: +3902891412638

E-mail: salvatore.sciascia@iulm.it

Accepted for publication in Journal of Family Business Strategy 


\title{
Women's involvement in Family Firms: \\ Progress and Challenges for Future Research
}

\begin{abstract}
This article reviews research on women's involvement in family firms according to a driversbehaviors-outcomes framework. Through a systematic review, we analyze and organize the content of 87 academic articles according to the type of involvement of women in family business, i.e. entrepreneurial entry, succession, career dynamics, and presence in family firms. We identify the drivers and outcomes of women's involvement in family firms at the firm, family, and individual level of analysis, as well as the contextual factors that may influence the aforementioned elements. Drawing on these findings, we identify relevant research gaps, propose a number of future research directions aimed at bridging these gaps, and suggest unexplored research avenues.
\end{abstract}

Keywords: Family Business, Business Family, Women's Involvement, Gender, Literature Review, Future Research.

\section{Introduction}

We define Women's Involvement in Family Firms as any act or process whereby women take part in the life of a family firm. Women's involvement in family firms has attracted increasing attention amongst practitioners and in the popular press. Since 2014, a couple of digital platforms have been launched to share the experiences, challenges, and best practices of women in family firms around the world. ${ }^{1}$ Forbes (2015) published an article to share and discuss the findings of a working paper titled "The effect of female executives: Positive for family firms, negative for public ones". EY (formerly Ernst \& Young) (2015) — through its Family Business Center of Excellence-published a report titled "Women in leadership" in relation to the findings from a global survey on female leaders, predicting that women will increasingly take the lead in family firms in the near future. Similarly, PricewaterhouseCoopers (2016) — through its PwC network—-published the "PwC Next Generation Survey 2016", a

\footnotetext{
${ }^{1}$ http://www.womeninfamilybusiness.org and http://weficommunity.org/
} 
report on the main issues of the next generation of female leaders in the context of family business.

Although recently attracting greater interest among practitioners, women's involvement in family firms has been a topic of academic inquiry since the 80s (e.g. Lyman, Salganicoff, \& Hollander, 1985), studied from a variety of disciplinary viewpoints, with different research methods and theoretical perspectives. This academic literature was reviewed in 2009: in her paper, Jimenez (2009) discusses some of the pathways that women typically take to assume management or leadership positions in family firms, looking in particular at their professional achievements (e.g. Rowe \& Hong, 2000; Vera \& Dean, 2005) while pointing out some of the obstacles and positive aspects of their involvement in family firms. More recently, in their book chapter, Gupta and Levenburg (2013) revised the same body of literature in a temporal perspective, identifying three generations of studies.

Although these prior reviews have been useful in mapping emerging research on women's involvement in family firms, too many years have elapsed since then. Moreover, the number of papers on the topic has more than doubled since 2009, in line with the significant growth of family business literature: publications have appeared not only in Family Business Review (e.g. Schröder, Schmitt-Rodermund, \& Arnaud, 2011) but also in other premier journals, such as Entrepreneurship Theory \& Practice (Dumas, 1992), Journal of Business Venturing (Cruz, Justo, \& De Castro, 2012), Small Business Economics (Hoffman, Junge, \& Malchow-Møller, 2015), and Management Science (Amore, Garofalo, \& Minichilli, 2014).

Thus, beyond the increasing attention that scholars have paid to reviewing the literature on women in family business (Cole, 1997; Jimenez, 2009; Gupta \& Levenburg, 2013), our review is particularly timely as it aims to take the academic debate to the next step with three main contributions. First, we offer a novel perspective by clustering existing contributions into four topics (entrepreneurial entry, succession, career dynamics, and presence) in line with the 
importance attributed to the temporal dimensions in family business research (Sharma, Salvato, \& Reay, 2014). In addition, we ascertain the mechanisms underlying the drivers-behaviorsoutcomes relationships that characterize women's involvement in family firms as well as the possible contextual effects. Last, we identify major research gaps and provide a detailed agenda to guide future research.

\section{Literature review methodology and descriptive findings}

To identify the relevant literature eligible for our review, we combined three databases: (a) Business Source Complete, one of the most complete databases of academic articles available, (b) Scopus, the largest abstract and citation database of peer-reviewed literature, and (c) JSTOR, a digital library of academic journals, books, and primary sources. We focused our search on articles published in academic journals up to December 2016, without a lower boundary for the timeframe. We used the following search algorithm of keywords in either the title or abstract: ("family business" or "family firm") and ("gender" or "woman" or "female" or "wife" or "daughter" or "sister" or "spouse"). The plurals of these keywords were also checked to ensure that any potentially relevant articles were not omitted. Through these three databases, we identified 184 articles. In addition, we double-checked on Google Scholar that all the existing 2016 articles were detected and found 2 articles in press at the time. Thus, we carefully read the 186 articles to identify the truly relevant ones.

We limited the literature review to influential articles published in established peerreviewed journals, as articles in academic journals can be regarded as validated knowledge and likely to have a major impact on the field (Ordanini, Rubera, \& DeFillippi, 2008; Podsakoff, MacKenzie, Bachrach, \& Podsakoff, 2005). Established journals are acknowledged to shape research in a field by setting new horizons for investigation within their frame of reference (Furrer, Thomas, \& Goussevskaia, 2008). We therefore considered that this approach provided an accurate and representative picture of relevant scholarly research. We excluded articles that 
were not written in English (5 articles), teaching cases (8), those not addressing business and management issues (36), not focused on family firms (19), not focused on women (29), and book reviews/interviews for book reviews $(2)^{2}$. This procedure led to a final population of 87 articles (marked in the reference list with an asterisk) published in 40 different academic journals. The list of journals that published at least 1 of these is reported in Table 1. Family Business Review published the most articles, given its focus and its relatively long history, followed by International Journal of Entrepreneurship and Journal of Family Business Strategy.

Table 1

Academic journals with more than one paper on women's involvement in family firms.

\begin{tabular}{lc}
\hline Journal & Number of articles \\
\hline Family Business Review & 27 \\
International Journal of Entrepreneurship & 5 \\
Journal of Family Business Strategy & 5 \\
International Small Business Journal & 4 \\
Entrepreneurship: Theory \& Practice & 3 \\
Corporate Governance: An International Review & 2 \\
International Journal of Cross Cultural Management & 2 \\
International Journal of Entrepreneurship \& Innovation Management & 2 \\
International Journal of Human Resource Management & 2 \\
Journal of Business Research & 2 \\
Journal of Management \& Organization & 2 \\
Journal of Small Business and Enterprise Development & 2 \\
\hline Journal of Small Business Management & 2
\end{tabular}

\footnotetext{
${ }^{2}$ For example, the Adrian \& Diana (2010) study was excluded because it does not address business/management issues; the Fairlie (2005) paper was not included because it does not focus on family firms; the Beach (1993) article was excluded because it does not focus on women's involvement.
} 
As Fig. 1 shows, literature on women's involvement in family firms has grown exponentially since 1985. According to Gupta and Levenburg (2013), there are three generations of studies on this topic.

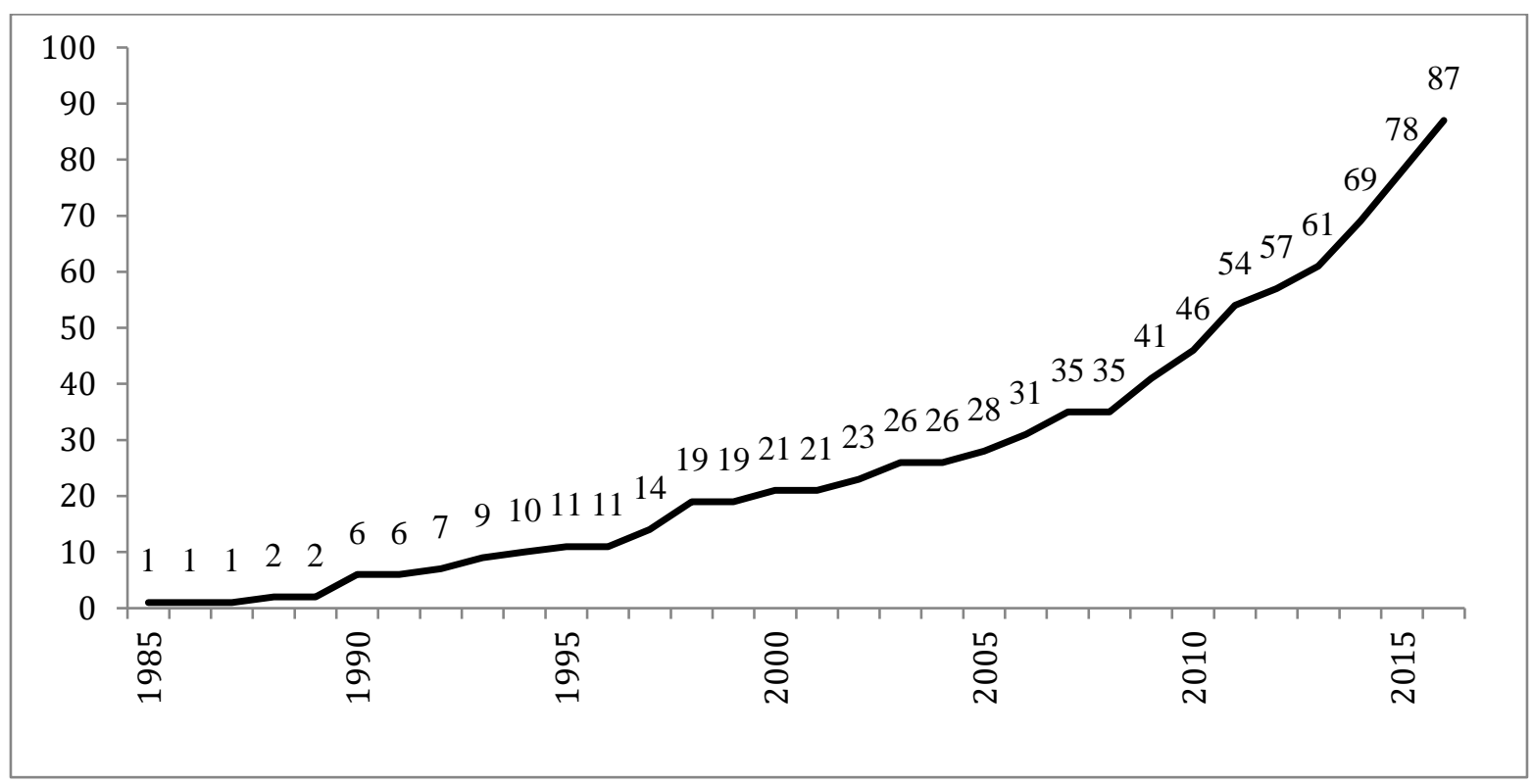

Fig. 1. Cumulative number of articles on women's involvement in family firms (1985-2016).

The first generation, published until the end of the 1990s, focused on the difficulties women encountered when joining their family firms and the lack of recognition for their work (Jimenez, 2009), also known as "women invisibility" (Gillis-Donovan \& Moynihan-Bradt, 1990). The research interest was grounded in the temporal context of these studies, when women's professional responsibilities were still considered secondary to their obligations toward the family (Lyman et al., 1985; Moen, 1992). Scholars investigated both the critical issues that hindered their involvement in family business, such as stereotyping and discrimination, women's attitudes towards their role (Salganicoff, 1990), and how traditional rules and roles have been challenged over time (Hollander \& Bukowitz, 1990; Frishkoff \& Brown, 1993; Cole, 1997). 
Later on, i.e. in the first decade of the new millennium, family business studies started focusing on the rise in women's careers and leadership (Curimbaba, 2002). Indeed, the second generation papers mostly focus on "the opportunities or advantages that family firms can offer women, the pathways that these women take to assume positions of management or leadership in these firms, and their achievements" (Jimenez, 2009, p. 53). This second generation of studies is not only characterized by a more optimistic view of women's involvement in family firms, but they also more frequently and explicitly mention the theoretical perspectives adopted, such as agency theory (e.g. Van den Berghe \& Carchon, 2003). In addition, methodwise, the authors of these second-generation studies more extensively leverage empirical evidence, albeit using small samples (e.g. Lussier \& Sonfield, 2007) and qualitative methods (e.g. Vera \& Dean, 2005).

The third wave of studies began at the end of the last decade with a growing number of papers published in this field. This wave of papers emphasizes the characteristics of the previous wave: first, maintaining an optimistic view of women's involvement in family firms while exploring the conditions that maximize its outcomes (e.g. Amore et al., 2014). Second, with the emergence of the Socio-Emotional Wealth (SEW) perspective, these studies are even more grounded in explicit theories (e.g. Cruz et al., 2012). Third, they constitute empirical studies to a greater extent, with the emergent use of large samples (e.g. Ahrens, Landmann, \& Woywode, 2015). Moreover, this generation of studies places more emphasis on the role of the context of their involvement in family firms (Gupta \& Levenburg, 2013).

Table 2 lists the theoretical perspectives employed in at least two articles. Worth noting is that around $50 \%$ of the identified articles do not explicitly state the adopted theoretical perspective, while the remainder from a wide range of scholars in different fields adopt a variety of theoretical lenses, thus paving the way for a multidisciplinary approach to studying 
women's involvement in family firms. Agency theory emerges as the most adopted theoretical perspective, as is the case in the entire family business literature.

Table 2

Theoretical perspectives explicitly adopted in at least two papers on women's involvement in family firms.

\begin{tabular}{lr}
\hline Theoretical perspective & Number of \\
& articles \\
\hline Agency theory & 6 \\
Family systems theory & 3 \\
Social learning theory & 3 \\
Socioemotional wealth perspective & 3 \\
Embeddedness perspective of entrepreneurship & 2 \\
Family FIRO (Fundamental Interpersonal Relationship Orientation) theory & 2 \\
Social exchange theory & 2 \\
Sustainable family business theory & 2 \\
Theory of planned behavior & 2 \\
Three-Dimensional Development Model & 2 \\
\hline
\end{tabular}

As regards the methodological approach, most of the identified articles are empirical (72 papers), while only a few are conceptual (15 papers). More than half the empirical articles adopt a qualitative method (35 papers), 33 rely on a quantitative approach, and only 4 employ mixed methods. The presence of a majority of qualitative articles in this area contrasts with the trend in overall family business research, which is instead largely dominated by the use of quantitative methodologies (De Massis, Sharma, Chua, \& Chrisman, 2012; Fletcher, De Massis, \& Nordqvist, 2016). Of the 35 qualitative articles, 2 are based on a single case, while 33 are based on multiple cases with 16 relying on more than 10 cases. On the other hand, of the 33 quantitative articles, 14 are based on samples larger than 500 cases. Most of the studies were conducted on mixed samples including both private and public companies, and micro-tomedium sized firms. They prevalently present cross-country analyses or offer findings claimed 
generalizable to any geographic context. Last, in terms of industry, most of the articles do not focus on a specific industrial sector.

\section{Analytical framework}

After reviewing the empirical and methodological aspects of extant research on women's involvement in family firms, we organized the selected literature into a framework as presented in Fig. 2. The framework identifies five major building blocks related to women's involvement in family firms: drivers, behaviors, outcomes, exo-context and chrono-context, as well as the relationships among them. This drivers-behavior-outcomes framework draws on some notable examples from family business literature, e.g. Lumpkin, Steier, and Wright (2011), De Massis, Frattini, and Lichtenthaler (2013), Feliu and Botero (2016). We conceive women's involvement in family firms as a behavior influenced by some specific drivers and able to produce outcomes. In this article, we define a driver as any factor that has an impact on women's involvement in family firms, whereas an outcome is any effect engendered by women's involvement in family firms. Building on Habbershon, Williams, and MacMillan (2003) who propose studying family business as a system comprised of three componentsthe firm, the controlling family, and the individuals - we also distinguish three levels of analysis in our framework, namely, the firm, the family, and the individual level. 


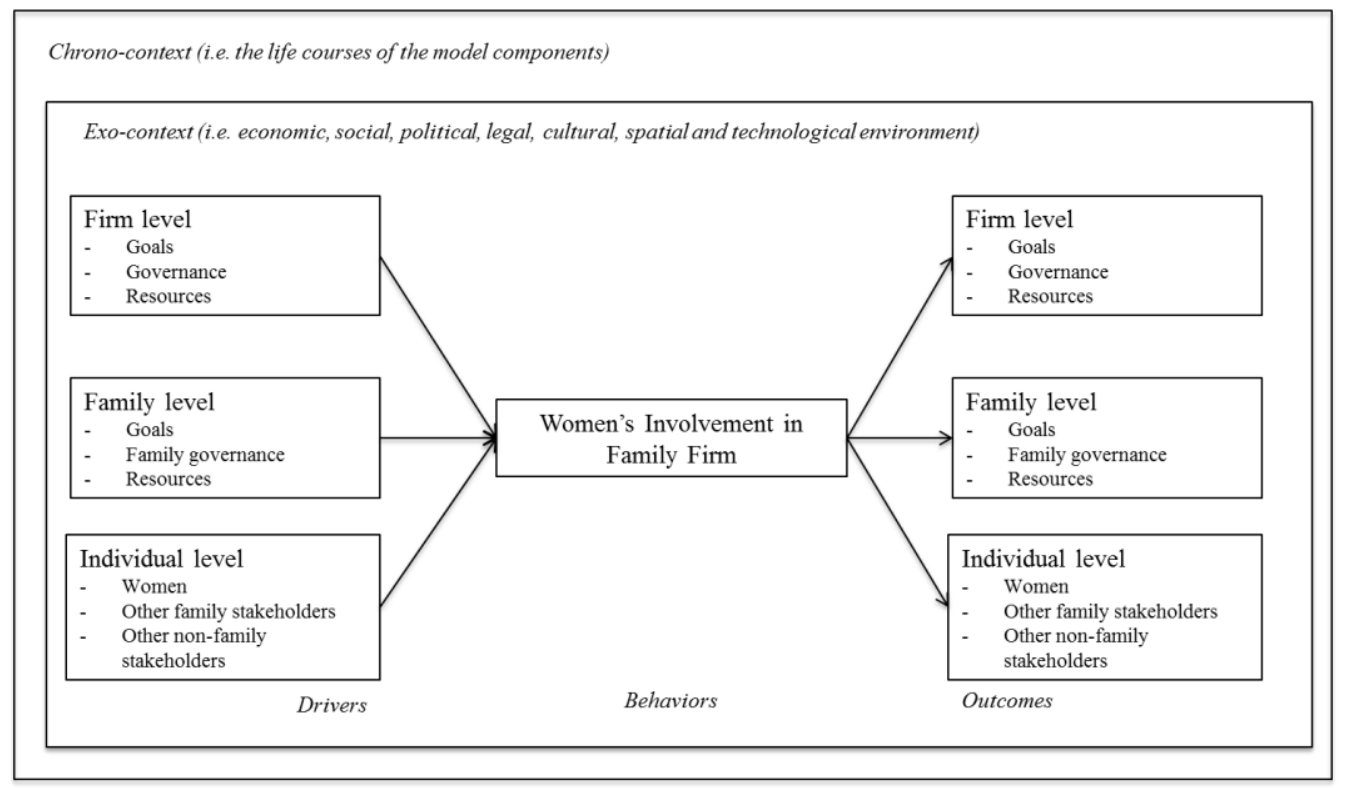

Fig. 2. The framework for organizing the selected research on women's involvement in family firms.

The first (firm) level follows Chua, Chrisman, Steier, and Rau (2012) where the factors that may influence or be influenced by women's involvement in family firms are firm goals, governance, and resources. At the second (family) level, the factors that may influence or be influenced by women's involvement in family firms are family goals, family governance, and resources. The third (individual) level relates to individual stakeholder characteristics. Among family firm stakeholders, worth distinguishing are women themselves and other family (i.e. their relatives) and nonfamily stakeholders (e.g. non-family employees).

At the firm and family level, goals, governance, and resources are strongly linked and may affect and be affected by strategic behaviors (Chrisman, Sharma, Steier, \& Chua, 2013). Therefore, the proposed framework includes all these elements as they may play a prominent role in analyzing literature on women's involvement in family firms.

We consider both economic and non-economic goals (Chrisman, Kellermanns, Chan, \& Liano, 2010) as potential drivers and outcomes on the firm and family levels of analysis (Kotlar \& De Massis, 2013). Consistent with extant research, we believe that family business is an interesting context to examine goal-setting processes and how goals may explain family firm 
behaviors and outcomes (Chrisman, Chua, Pearson, \& Barnett, 2012; Chrisman \& Patel, 2012; Chua, Chrisman, \& Sharma, 1999; Habbershon et al., 2003). In particular, we analyze the articles highlighting both firm-centered and family-centered goals to discuss whether they affect or are affected by women's involvement in family firms.

Despite the plethora of divergent perspectives and definitions of corporate governance, we refer here to corporate governance as "concerned with the nature of the interactions and relationships between the firm and its various stakeholders in the process of decision-making and in terms of control over firm resources" (Huse, 2007, p.31). Furthermore, we consider corporate governance at both the firm level (i.e. managerial governance) and family level (i.e. family governance) (Carney, 2005). Firm level governance refers to "distinct incentives, authority structures, and norms of accountability that generate specific organizational propensities" (Carney, 2005, p. 249). Indeed, firm governance deals with ownership, board, leadership, and management issues focused on mechanisms such as board of directors and management teams. Family governance instead includes the web of relationships that exist among family members aside from the structures they have created, and usually unfolds in the adoption of governance mechanisms, such as family councils and family constitutions (Angus, 2005). Accordingly, we review the literature with a specific focus on governance elements related to the relationship between owners and managers, as well as with other stakeholders (board of directors, employees, etc.) to show what governance aspects may affect or are affected by women's involvement in family firms.

Resources are productive assets owned by the firm, which can be characterized as tangible (financial and physical), intangible (organizational culture, technology, reputation) or human (Grant, 1991). According to Sirmon and Hitt (2003), family firms have specific resources, such as a distinctive social capital, patient capital—referring to financial capital invested without threat of liquidation for long periods (Dobrzynski, 1993) — and survivability capital — the 
pooled personal resources that family members are willing to loan, contribute, or share for the benefit of the family business (Haynes, Walker, Rowe, \& Hong, 1999; Horton, 1986; Dreux, 1990). More generally, the bundle of resources distinctive to a family firm is labeled as “familiness" (Habbershon \& Williams, 1999; Pearson, Carr, \& Shaw, 2008). Incorporating the temporal element and the different forms of capital (Sharma, 2008), familiness can be explicated as the combination, at a point in time, of existing stocks of social, human, financial, and physical capital resulting from interactions between family and business systems (Habbershon \& Williams, 1999; Habbershon et al., 2003). Therefore, the resources that may affect or be affected by women's involvement in family firms are examined at both the family and firm level of analysis.

The proposed framework also includes individual level factors, i.e. the mechanism by which women's involvement in family firms influences or is influenced by individual stakeholders. In particular, the analysis of the selected articles discusses not only the role of women themselves, but also the role of other stakeholders, divided into two main categories: family stakeholders and non-family stakeholders. Such a distinction is meaningful, as the presence of these two stakeholder "factions" is a distinctive feature of family firms (Minichilli, Corbetta, \& McMillan, 2010). We adopt a general definition of stakeholders as any group or individual who may affect or be affected by the achievement of organizational objectives (Freeman, 1984).

Finally, in light of the suggestions of Wright, Chrisman, Chua, and Steier (2014), the above-mentioned elements (women's involvement in family firms, the drivers, and outcomes) have to be contextualized to avoid conceptual inadequacies and empirical indeterminacies. First, women's involvement in family firms occurs in an institutional or exo-context that refers to the economic, social, political, legal, and cultural institutions, as well as the spatial settings and technological environments in a given society or state. All these factors may affect the 
behaviors, drivers, and outcomes as well as their relationships. In addition, women's involvement in family firms is affected by a specific chrono-context, which includes factors that consider evolutionary or punctuated changes in the institutional or organizational environment affecting the firm (Wright et al., 2014).

What follows is an exhaustive and updated review of the literature, including the most recent publications that have significantly contributed to the field's growth.

\section{Overview of prior research}

The analysis of the 87 selected studies led to the identification of four recurrent topics corresponding to four types of women's involvement in family firms: entrepreneurial entry, succession, career dynamics, and presence. Fig. 3 shows the classification of these topics, consistent with the importance attributed to the temporal dimensions in family business research (Sharma et al., 2014), and reports how the selected papers are distributed among the four types of women's involvement in family firms.

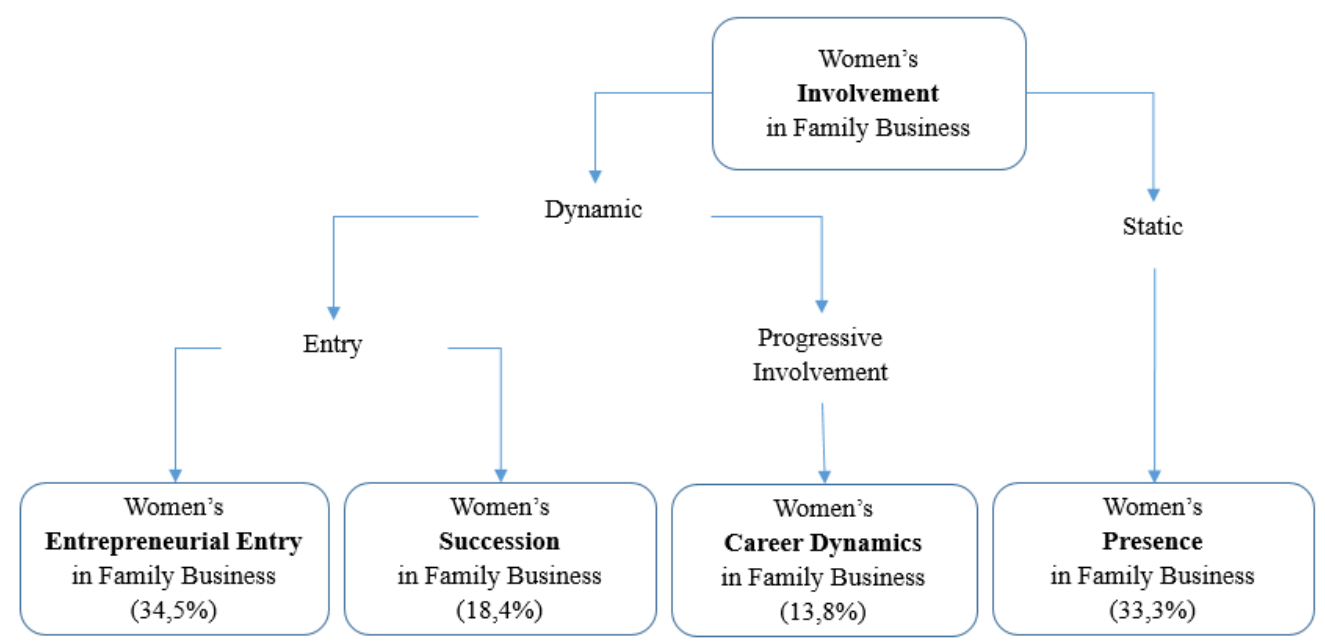

Fig. 3. A classification of the four types of women's involvement in family firms.

The first three types of women's involvement in family firms (i.e. entrepreneurial entry, succession, and career dynamics) are characterized by dynamism: the articles on 
entrepreneurial entry refer to women starting up a firm with their husbands and/or other family members. The articles on succession refer to women who obtained a leadership role by succeeding an incumbent leader. The articles on career dynamics refer to the progressive involvement of women in the family firm. Conversely, the last type of women's involvement in family firms (i.e. women's presence) is static, referring to the presence of women who had already entered the family business.

This section presents a review of research on women's involvement in family firms and is organized into five sub-sections, one for each type of women's involvement in family firms and one on the role of the exo- and chrono-contexts. The drivers and outcomes of the four types of women's involvement in family firms are examined at the firm, family, and individual level. Table 3 offers a synoptic view of our findings. 
Table 3. Drivers and outcomes of the four types of women's involvement in family firms.

\begin{tabular}{|c|c|c|c|c|c|c|c|c|}
\hline & \multicolumn{2}{|c|}{ Women's Entrepreneurial Entry } & \multicolumn{2}{|c|}{ Women's Succession } & \multicolumn{2}{|c|}{ Women's Career Dynamics } & \multicolumn{2}{|c|}{ Women's Presence } \\
\hline \multirow[t]{2}{*}{$\begin{array}{l}\text { No. of } \\
\text { articles } \\
\end{array}$} & \multicolumn{2}{|c|}{30} & \multicolumn{2}{|c|}{16} & \multicolumn{2}{|c|}{12} & \multicolumn{2}{|c|}{29} \\
\hline & Drivers & Outcomes & Drivers & Outcomes & Drivers & Outcomes & Drivers & Outcomes \\
\hline $\begin{array}{l}\text { Firm } \\
\text { level }\end{array}$ & & $\begin{array}{l}- \text { Firm performance } \\
\text { - Family support } \\
\text { - Trust } \\
\text { - Strategic decisions } \\
\text { - Growth } \\
\text { orientation }\end{array}$ & - Gendered norms & & $\begin{array}{l}\text { - Glass ceiling } \\
\text { - Family business } \\
\text { structure }\end{array}$ & & $\begin{array}{l}\text { - Organizational } \\
\text { culture }\end{array}$ & $\begin{array}{l}\text { - Performance } \\
\text { - Corporate Social } \\
\text { Responsibility } \\
\text { - Succession } \\
\text { Planning } \\
\text { - Organizational } \\
\text { tensions }\end{array}$ \\
\hline $\begin{array}{l}\text { Family } \\
\text { level }\end{array}$ & $\begin{array}{l}\text { - Spousal support } \\
\text { - Family tradition } \\
\text { and culture }\end{array}$ & $\begin{array}{l}\text { - Marriage success } \\
\text { - Marital equity and } \\
\text { equality }\end{array}$ & $\begin{array}{l}\text { - Family } \\
\text { composition } \\
\text { - Predecessors' } \\
\text { preferences } \\
\text { - Relationships } \\
\text { among family } \\
\text { members of the } \\
\text { two generations }\end{array}$ & $\begin{array}{l}\text { - Lower conflicts } \\
\text { - Shared meaning, } \\
\text { collaboration and } \\
\text { integration among } \\
\text { family members }\end{array}$ & $\begin{array}{l}\text { - Family moral } \\
\text { support, solidarity } \\
\text { and love }\end{array}$ & & $\begin{array}{l}\text { - Rules and norms } \\
\text { in terms of gender } \\
\text { roles }\end{array}$ & \\
\hline $\begin{array}{l}\text { Individual } \\
\text { level }\end{array}$ & $\begin{array}{l}\text { - Entrepreneurial } \\
\text { imagination } \\
\text { - Empathy } \\
\text { - Modularity } \\
\text { - Self-organization } \\
\text { - Education level } \\
\text { and area } \\
\text { - Previous } \\
\text { entrepreneurial } \\
\text { experience } \\
\text { - Alertness } \\
\text { - Leadership } \\
\text { - Invisibility } \\
\text { - Gender of the self- } \\
\text { employed parent }\end{array}$ & $\begin{array}{l}\text { - Female } \\
\text { entrepreneurs' } \\
\text { satisfaction }\end{array}$ & $\begin{array}{l}\text { - Personality traits } \\
\text { of the female } \\
\text { successor } \\
\text { - Work-family } \\
\text { conflict } \\
\text { - Perception of } \\
\text { gender inequality } \\
\text { - Rivalry with non- } \\
\text { family employees } \\
\text { and mothers } \\
\text { - Leadership style } \\
\text { and gender of the } \\
\text { incumbent }\end{array}$ & - Inclusion & $\begin{array}{l}\text { - Business Vision } \\
\text { - Risk-aversion } \\
\text { - Visibility } \\
\text { - Interpersonal } \\
\text { network } \\
\text { - Leader's gender }\end{array}$ & & $\begin{array}{l}\text { - Educational level } \\
\text { - Family } \\
\text { membership } \\
\text { - Outside } \\
\text { experience } \\
\text { - Husbands in bad } \\
\text { health } \\
\text { - Social capital } \\
\text { - Psychological } \\
\text { ownership }\end{array}$ & $\begin{array}{l}\text { - Identity } \\
\text { questioning }\end{array}$ \\
\hline
\end{tabular}




\subsection{Women's entrepreneurial entry in family firms}

The 30 articles that focus on entrepreneurial entry identify several drivers and outcomes related to this type of women's involvement in family firms.

Drivers of women's entrepreneurial entry in family firms. No drivers emerge at the firm level, while the main drivers of women's entrepreneurial entry in family business at the family level are spousal support, family tradition, and culture. Without spousal support, it would be difficult for women to start up a family business. Specifically, the support offered by the spouse may be emotional/psychological, practical, or a combination of both (Blenkinsopp \& Owens, 2010). Further, if spouses share a common vision of the business goals, risks, and objectives, then women are more likely to launch an entrepreneurial project with their husbands (Van Auken \& Werbel, 2006). The husband's willingness to accommodate the changes required by the wife's business is also essential, improving both family and business life (Nikina, Shelton, \& Leloarne, 2015). Family tradition and culture are further factors that highly affect the probability of a woman becoming a family entrepreneur (Robinson \& Stubberud, 2012; Gundry \& Ben-Yoseph, 1998). Female entrepreneurship is strongly supported by the family of origin, especially in some cultural contexts, such as Sudan and Saudi Arabia (Welsh, Memili, Kaciak, \& Ahmed, 2013; Welsh, Memili, Kaciak, \& Al Sadoon, 2014). Indeed, family moral support can be deemed a key driver and a form of social capital (Burt, 1997; Sirmon \& Hitt, 2003; Pearson et al., 2008).

Women's personal characteristics are considered the main drivers of women's entrepreneurial entry in family firms at the individual level. Factors, such as entrepreneurial imagination, empathy, modularity, and self-organization (Barrett, 2014), act as drivers of women's entrepreneurial entry in family business. These are complemented by human capital variables, such as education level and area, previous entrepreneurial experience (Hisrich \& Fülöp, 1997), and alertness, i.e. the ability of women to identify opportunities and exploit the 
resources needed for their entrepreneurial strategy (Kickul, Jianwen, Gundry, \& Iakovleva, 2010). Moreover, a powerful leadership role may characterize female entrepreneurial entry in family business (Hamilton, 2006). Indeed, "independent women" who take the lead in making decisions are in control of the business, care about external relations, and are more likely to become entrepreneurs than "hidden women" who instead mix domestic and market relations that are usually exploited by men (Dhaliwal, 2000). Accordingly, Gherardi (2015) distinguishes different women's roles, such as business creators, "co-authoresses" of the firm (p.655), responsible wives, and second-generation owners. Depending on the role played, different types of resources are mobilized, such as passion (business creator), ability to share decisions (co-authoress), be the helpmate (responsible wife), and follow in the father's footsteps (second-generation owner). In terms of human capital, both male and female founders benefit from higher education and experience (O'Connor, Hamouda, McKeon, Henry, \& Johnston, 2006). An important driver that may hinder women's entrepreneurial entry in family firms is the so-called "women invisibility" within the organization, i.e. lack of recognition of their critical role in the business (Karatas-Özkan, Erdogan, \& Nicolopoulou, 2011): some women may think that launching a family business is not worthwhile if they believe that their role would not be recognized. An additional driver affecting women's entrepreneurial entry in family business is the gender of the parent who is self-employed, as only when the father is self-employed does the likelihood of the daughter becoming an entrepreneur increase (Hoffmann et al., 2015).

Outcomes of women's entrepreneurial entry in family firms. In spite of this plethora of drivers that either foster or hamper women's entrepreneurial entry in family firms, relatively few outcomes have emerged. At the firm level, the performance of female-controlled family firms is positively affected by the female entrepreneur's age (Zapalska, Bugaj, \& Rudd, 2005) and her ability to obtain family support, a relevant condition for coping with personal and 
business problems (Welsh, Memili, Kaciak, \& Ochi, 2014). An interesting insight emerges from the copreneurship literature stream regarding governance structure and the related mechanisms: trust engendered in the business through the couples' emotional connection, synergy, and commitment to the business, helps copreneurs to keep working together after divorce, to the benefit of family firm longevity (Cole \& Johnson, 2007).

Looking at strategic choices, women tend to prefer starting family businesses in more familiar fields, while men may explore unfamiliar ones. In addition, family firms owned by women usually focus on one industry, while those owned by men are more likely to implement unrelated diversification (Smith, 2009, 2014). Last, women leaders in copreneurial ventures appear to be oriented towards growth rather than meeting their living standards, at least in hightech industries (Kuschel \& Lepeley, 2016).

The outcomes of women's entrepreneurial entry in family business at the family level include marriage success, as this strongly depends on women's work-life balance (Wu, Chang, \& Zhuang, 2010). Marital equity and equality constitute further outcomes: marital equity is a measure of "how satisfied each spouse is with the division of responsibilities" (Marshack, 1994), while equality relates to how equal the efforts, roles, and rewards among the partners are (Millman \& Martin, 2007). Based on this definition, it is clear that the principle of equity, even more than equality, affects marital and personal satisfaction for dual-career couples (Marshack, 1993, 1994). Copreneurial businesses where spouses are equal partners engaging in collaborative power interactions are likely to result in a more productive team (Hedberg \& Danes, 2012). Equality may not be there at the beginning of the copreneurial process, but can grow over time: women may gradually increase their involvement and commitment to the business, going from "classic copreneurship" into "full ownership" (Fletcher, 2010). Likewise, Deacon, Harris, and Worth (2014) discuss equality between copreneurs, asserting that the skills, responsibilities, and roles of the female and male partners are often complementary and 
thus create value not only for the business but also for the family. A crucial factor required for concurrent business and marriage success is role clarity between wife and husband (Farrington, Venter, Eybers, \& Boshoff, 2011).

Last, at the individual level, female entrepreneurs' satisfaction in family business is the only outcome identified: a recent quantitative study found that this depends on the absence of personal rather than business problems (Lakshmi Bala, Kavitha, \& Suresh Kumar, 2016).

\subsection{Women's succession in family firms}

Drivers of women's succession in family firms. The analysis of the 16 articles that focus on succession highlights a broad set of drivers for this type of women's involvement in family firms. In particular, at the firm level, the presence of automatically activated gendered norms, such as primogeniture, may impede female succession (Overbeke, Bilimoria, \& Perelli, 2013).

At the family level, the main drivers of women's succession in a family business relate to family composition: intra-family successions are significantly more likely to occur when the predecessor has a son, although female family successors seem to be equipped with significantly higher levels of human capital (Ahrens et al., 2015). Consistently, the father's preference for male family members as successors is an additional factor that may inhibit female succession (Glover, 2014). Conversely, some drivers support the relationship between fathers and daughters, such as early socialization in the family business, better communication, and the quality of the relationship between incumbent and successor (Smythe \& Sardeshmukh, 2013). Father-daughter relationships are generally not as competitive as father-son relationships (Galiano \& Vinturella, 1995), thus building a good relationship with fathers/husbands should be easier for daughters compared to sons.

At the individual level, personality traits play a relevant role in female succession: the more the daughter is agreeable, i.e. caring, altruistic, and trusting, the more she would prefer a job outside the family business. On the contrary, the tougher and less open she is, the more she 
would prefer taking over her parents' business (Schröder et al., 2011). Among the personality traits, individual identity may also influence women's succession in family firms. When identity structuring is harmonious and stable, the daughter develops the identity of "caretaker of the king's gold", with which she can take care of herself, her father, and the business (Dumas, 1990). Finally, strong motivation and a growth orientation may increase her likelihood of being selected as the family business' designated successor (Mathew, 2016).

Another driver that could impede female succession is work-family conflict (Vera \& Dean, 2005): women may have problems in raising a family if working too many hours per day (Cadieux et al., 2002), defining their own identity, and meeting the expectations of their close community (Salganicoff, 1990). Moreover, daughters may receive confusing messages from parents who may push them to raise future generations while at the same time complaining if they disregard the business (Cole, 1997).

Gherardi and Perrotta (2016) also find that women's perception of gender inequality affects the way female leaders prioritize familial rather than industrial engagement, and may lead to less legitimacy with respect to males in the eyes of relatives and firm stakeholders. Last, women's rivalry with non-family employees could also negatively affect father-daughter succession (Vera \& Dean, 2005), since employees may feel threatened by the daughter's role as "second-in-command" (Dumas, 1992). Something similar may occur with mothers, who feel threatened by the daughter's role as the father's confidant (Dumas, 1992).

Incumbents can deeply influence the succession process. In the case of male predecessors, the incumbent's leadership style may play a relevant role: a benevolent paternalistic style may increase the possibility of successful succession for a daughter rather than a son (Cicellin, Mussolino, \& Viganò, 2015). Female incumbents, instead, can bring credibility to their successors thanks to their self-confidence and ability to transmit positive values (Koffi, Guihur, Morris, \& Fillion, 2014), but lack of planning may hinder succession (Cadieux, Lorrai, \& 
Hugron, 2002) unless she has the right skills and high credibility (Sharma, Chua, \& Chrisman, 2000; Chrisman et al., 1998). Also acknowledged - from a psychological point of view - is that it is more difficult for a female CEO than a male CEO to choose the only son/daughter-in-law as successor when he/she is not ambitious, assertive and competent: when a daughter-in-law becomes the successor, it is usually because she has outstanding skills (Kaslow, 1998).

Outcomes of women's succession in family firms. Prior research also identifies some outcomes of women's succession in family business: Haberman and Danes (2007) find that women in a father-daughter succession experience feelings of inclusion, an individual level factor resulting in fewer conflicts and higher levels of shared meaning, collaboration, and integration among family members at the family level.

\subsection{Women's career dynamics in family firms}

Drivers of women's career dynamics in family firms. We identified 12 contributions examining the determinants of women's career advancement in family firms, yet no insights emerge on the outcomes of such career progression dynamics. At the firm level, "the unseen, yet unbreakable barrier that keeps minorities and women from rising to the upper rungs of the corporate ladder, regardless of their qualifications or achievements" (Federal Glass Ceiling Commission, 1995, p. 4) is known as the "glass ceiling". This is found in large, small, and medium-sized family firms, although family-owned SMEs seem to provide a more favorable environment for women to attain a position on the board of directors (Songini \& Gnan, 2009).

The related concept of women's invisibility is also recognized as a barrier to women's careers in family firms. "Invisible women are defined as women with low or no physical visibility in the workplace, sharing a lack of acknowledgement, title and compensation" (GillisDonovan et al., 1990, p.153). Women's invisibility manifests when their job is not properly formalized, articulated, and acknowledged, potentially leading to slow and unsatisfactory careers despite their crucial contributions, in some cases, to family firm success. Fortuitously, 
women increasingly play more active and successful roles in family firms (Frishkoff \& Brown, 1993). Indeed, daughters and wives hold more leadership positions in family firms than in the past, even in traditionally male-dominated industries (Nelton, 1998; Barrett \& Moores, 2009), and are more represented on corporate boards (Bianco, Ciavarella, \& Signoretti, 2015).

The family business structure is considered an important additional driver, as it influences the degree of visibility of the daughter's experience in the family firm, which in turn is expected to influence women's career dynamics. The lowest degree of visibility (invisible daughters) is usually observed when daughters are part of large families with numerous sons involved in the business and their career progress is hence more difficult. A medium degree of visibility (professional daughters) is usually found when they operate in mature firms with complex ownership structures and their inclusion is occasionally seen as a way to resolve some conflicts within the family. The highest degree of visibility (anchor daughters) is identified when daughters work in family firms with predominantly female children or a daughter as the first child considered essential to the business (Curimbaba, 2002).

Scholars have mainly focused on individual level drivers. One of the stereotypes found in literature depicts women as uninterested in a career in family firms. However, this has recently been disconfirmed by Block, Fisch, Lau, Obschonka, and Presse (2016) who find that women are more risk-averse than men and that family firms are particularly attractive for risk-averse employees. Women find working for the family firm more attractive and rewarding compared to non-family firms, although they are challenged by a masculine environment that makes them conceal their typical feminine characteristics when they become CEOs (Vadnjal \& Zupan, 2011).

According to Dumas (1998), when a daughter enters the business, her individual characteristics may affect the career dynamics, as she may have a reactive, proactive, or evolving business vision in the "participation" phase. If she has a reactive vision, she behaves 
as an ordinary employee, merely carrying out her tasks. If she has a proactive vision, she has a clear image of the business and a desire to improve it. If she has an evolving vision, she is aware of the business and her own potential in managing it, with a gradually increasing sense of self-esteem and greater awareness of her skills developed through experience and education. A daughter's participation reaches its peak in the "leadership" phase, when she is selected by her parents to become a leader, as they recognize her interest in the business, her skills, education, leadership ability, and prior experience. In this phase, family moral support, solidarity, and love may be considered relevant drivers.

Among the individual drivers, interpersonal networks are also found to provide greater opportunities for career stability and guidance (Lyman, 1988). Indeed, many successful women in family firms develop alliances with other women, establishing motivational networks to encourage each other to find a balance between family and business needs (Lyman et al., 1985).

Last, not only are the women's characteristics themselves essential in determining their career, but also those of the firm leader at the time of entry. In this regard, Kilkolly-Proffit (2013) shows that daughters become acquainted with the family business earlier and easier when the leader is their mother rather than their father.

\subsection{Women's presence in family firms}

Our review highlights 29 articles with a focus on women's presence in family business, examining an extensive number of drivers and outcomes.

Drivers of women's presence in family firms. In terms of drivers at the firm level, prior literature suggests that higher formalization and a clear division of labor helps clarify women's roles in business (Heinonen \& Stenholm, 2011) and their contributions (Gillis-Donovan et al., 1990). The perception of the relevance of these drivers was found to be higher among male employees (Van der Merwe, 2009). 
At the family level, families with rigid rules and norms in terms of gender roles may prevent women's presence in the family firm (Rothausen, 2009). However, women generally have more advantages than men in family firms, especially flexibility in work schedules and job security for maternity leave (Salganicoff, 1990).

At the individual level, one of the main drivers of women's presence in family firms is their higher educational level (Aronoff, 1998) and being members of the owning family (Singh, Point, Moulin, \& Davila, 2015). Nevertheless, some scholars point out that a high likelihood of wives' participation in the family firm is often advantageous if previously employed in positions outside the family firm or when husbands are not in good health, especially in some business areas such as services and sales (Rowe \& Hong, 2000). Overall, compared to men, women's business skills and social capital are found to negatively affect their participation in the family firm (Lerner \& Malach-Pines, 2011). Conversely, psychological ownership, defined as "a state in which individuals feel as though the target of ownership (or a piece of that target) is theirs" (Pierce, Kostova, \& Dirks, 2003, p. 86) is an important driver to understand the development of women's contributions to the family firm (Heinonen \& Stenholm, 2011).

Outcomes of women's presence in family firms. Several possible outcomes of women's presence in family firms are found. At the firm level, some scholars find that women's presence on boards seems to have a negative impact on family firm performance (Mínguez-Vera \& Martin, 2011), since women are more risk-averse - a key performance driver (Amran, 2011). Moreover, in case of divorce, the financial performance of small family firms may decrease substantially (Galbraith, 2013). Conversely, Amore et al. (2014) find that female-led companies perform significantly better at high levels of female directorship (i.e. percentage of female directors), especially when female directors do not belong to the family (Amore et al., 2014). Similarly, Cruz et al. (2012) find that women managers know how to handle conflict between socioemotional and financial goals better than men, thus improving firm performance 
(Cruz et al., 2012). Danes, Stafford, \& Loy (2007) find that the business owners' gender interacts with management practices to influence performance. In particular, personnel management practices have a much larger effect on gross revenue for female than male owners. In a recent article, Vandebeek, Voordeckers, Lambrechts, and Huybrechts (2016) define gender as a fault line in the board of directors that may affect board control and service performance positively or negatively depending on the adoption or absence of board evaluations, thus providing additional evidence of the dual nature of women's involvement in family firms.

Some recent studies find a positive association between the presence of female directors and CSR (Peake, Cooper, Fitzgerald, \& Muske, 2015; Sundarasen, Je-Yen, \& Rajangam, 2016), whereas Rodríguez-Ariza, Cuadrado-Ballesteros, Martínez-Ferrero, and GarcíaSanchez (2017) do not find a significant effect in their study.

Lussier and Sonfield (2007) analyze the relationships between the time spent in strategic management activities and the percentage of women involved in firm operations, but find nonsignificant results. Harveston, Davis, and Lyden, (1997) find that business owner gender interacts with some organizational variables to influence the comprehensiveness of the succession planning process and its drivers. In particular, organizational size and formality have a stronger effect on female-led businesses than on male-led businesses.

Some articles deal with governance challenges, such as role clarity and agency problems. On the one hand, in the case of copreneurs, tensions may arise when there is no role clarity (Hollander \& Bukowitz, 1990; Danes \& Olson, 2003). On the other hand, tensions could also ensue in the father-daughter business relationship. From an agency theory perspective, if the father is a shareholder and the daughter is a manager, the father (principal) usually gives priority to the performance of his firm, while the daughter (agent) may not (Van den Berghe \& Carchon, 2003). 
At the individual level, women are often more likely to question their authentic self and their identity in the boundaries among family, work and the individual's own spaces (Aygören \& Nordqvist, 2015).

\subsection{The role of the exo- and chrono-context}

Of the 87 articles analyzed, 38 deal with the impact of the economic, social, political, legal, cultural, spatial and/or technological environment on women's involvement in family firms. Most focus on several aspects simultaneously, especially those of a spatial, cultural, and social nature, while only a few focus on the economic, political, and legal aspects affecting women's involvement in family firms.

The articles that take into consideration spatial influence (21 papers) mostly focus on small countries (such as Hungary, Ireland, Italy, Malaysia and Slovenia). Only 2 of these focus on least developed countries such as North Sudan (Welsh et al., 2013) and some East African countries including Burundi, Ethiopia, Eritrea, Madagascar, Malawi, Mozambique, Rwanda, Somalia, Uganda and Zambia (Smith, 2009), while the majority focus on developing and developed countries.

Culture is frequently cited (in 16 papers) as a contextual factor affecting women's succession (Overbeke et al., 2013) and career (Cole, 1997): women in family business continue to struggle with some limitations imposed by stereotypes, which may particularly affect their career advancements in the absence of a careful evaluation of their potential and performance. Some scholars highlight the importance of considering the cultural characteristics and the roles assigned to women in specific countries such as Turkey (Karatas-Özkan et al., 2011). In Slovenia, for example, culture, business climate, and government policies are not perceived as business-friendly for women's involvement in family firms (Vadnjal \& Zupan, 2011). Additionally, as Gherardi (2015) shows, specific contexts, such as Trentino (a region in Northern Italy located in the mountains without a nearby metropolitan conglomerate), have a 
traditional culture regarding gender relations where gender, social status, ethnicity, and religion interact in constructing social categories that define women as non-paid 'helpmates' for the men's paid work. Lerner and Malach-Pines (2011) investigate gender differences in family firms among ten countries and find that differences exist mostly in terms of business skills and social capital. Last, Amore et al. (2014) find that the positive effect of the co-presence of female leaders and directors on profitability decreases when the family firm is located in geographic areas characterized by gender prejudice.

Only two contributions highlight the influence of the chrono-context on women's involvement in family firms. Beyond the call for the adoption of temporal considerations in the study of diversity in family firms (Howorth, Rose, Hamilton, \& Westhead, 2010), MeronoCerdan and López-Nicolás (2017) offer unique insights in this sense, finding that women are more frequently involved in second and subsequent generation family firms compared to first generation family firms.

\section{Future research agenda}

The framework used to organize the findings from prior research has also allowed us to identify some research gaps emerging from our literature review. Starting from these research paucities, we outline some opportunities for future research (see Table 4).

Table 4.

Suggested directions for future research on women's involvement in family firms.

\begin{tabular}{ll}
\hline RESEARCH GAPS & RESEARCH QUESTIONS \\
\hline RG\#1: Investigating the mutual & RQ\#1A: What corporate entrepreneurship activities (e.g., corporate venturing, innovation, \\
relationship between corporate & strategic renewal) affect women's entrepreneurial entry in family firms? \\
entrepreneurship and women's & RQ\#1B: How do women's succession, career dynamics, and presence affect corporate \\
involvement in family firms. & entrepreneurship in family firms?
\end{tabular}




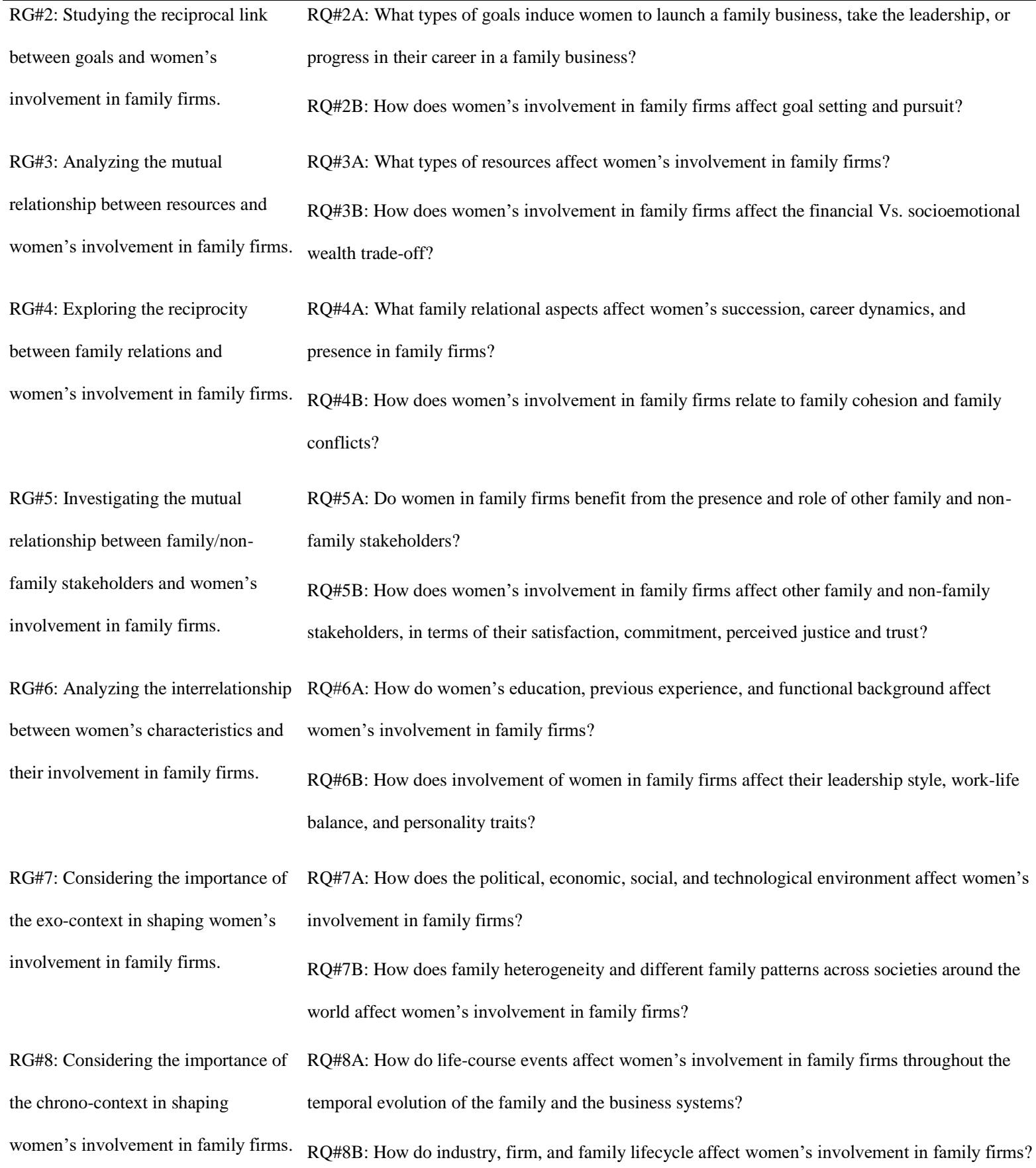

RQ\#8B: How do industry, firm, and family lifecycle affect women's involvement in family firms?

A first major research gap concerns the role of corporate entrepreneurship activities that can act as drivers of women's entrepreneurial entry, as well as outcomes of succession, career dynamics, and presence of women in family business. Corporate entrepreneurship is the process through which established corporations create a new organization or instigate renewal or innovation within the organization (Sharma \& Chrisman, 1999). From an entrepreneurial 
opportunity identification and development perspective (Ardichvili, Cardozo, \& Ray, 2003), women can leverage new opportunities, such as M\&As, spin-offs, or new international ventures, to enter the family business. Although some studies show that corporate venturing (Marchisio, Mazzola, Sciascia, Miles, \& Astrachan, 2010) and spin-offs (Au, Chiang, Birtch, \& Ding, 2013) have been used to test the next generation's succession intentions, we do not know whether they also lead women to launch their own businesses afterwards, and to what extent. In addition, a complementary research direction could consider whether women's career dynamics, succession, and presence may in turn affect new corporate entrepreneurship activities, thus contributing with their involvement in the family business to spot new opportunities.

The analysis of extant research also highlights a dearth of studies on the reciprocal link between family business goals (Gagné, De Massis, \& Sharma, 2014) and women's involvement in family firms, i.e. a second research gap. In particular, future research might consider the goal setting processes (Kotlar \& De Massis, 2013), given the coexistence of economic and non-economic goals as well as family- and non-family-centered goals (Chrisman et al., 2012, 2013). For example, looking at succession, Kotlar and De Massis (2013) suggest that in proximity to generational transitions, goal diversity is more strongly expressed in family business. Given that a father-daughter transition is found to be smoother than a father-son transition (Galiano \& Vinturella, 1995), it would be relevant to investigate the goal-setting process in these two different situations, thereby providing relevant gender-related insights for family firms struggling with the succession process. Future studies could focus on the causal link between the type of goals set by family firms and women's entrepreneurial entry, career dynamics, and presence. Moreover, a compelling research question concerns the reciprocal effect of women's involvement in family firms on goal setting and pursuit, i.e. the mutual relationship between recent transition to a female CEO, women's career or presence, and the 
prioritization of economic versus non-economic goals, or family-centered versus non-familycentered goals.

The role of resources as both drivers and outcomes of women's involvement in family firms also deserves attention in future research. The use of the resource-based view in family business has led to the concept of familiness (Habbershon \& Williams, 1999), while the dynamic capabilities perspective has been useful to study how to deploy and exploit the bundle of resources in overlapping family and business systems (Sirmon \& Hitt, 2003). Although these theoretical perspectives have been adopted, for example, to discuss succession in family business (e.g. Cabrera-Suárez, De Saá-Pérez, \& García-Almeida, 2001), gender issues have been neglected thus far. Future research may consequently build on these theoretical lenses to identify those resources that are particularly relevant to facilitating women's career dynamics and predicting their presence in family firms. Nevertheless, the opposite relationship might also be the subject of future studies on how women's involvement in family firms may affect the three characteristics of family capital, i.e. storability, transformability, and interaction (Danes, Stafford, Haynes, \& Amarapurkar, 2009) as well as the forms of family business wealth, i.e. financial and socioemotional (Gómez-Mejía, Núñez-Nickel, Jacobson, \& MoyanoFuentes, 2007; Kotlar, Signori, De Massis, \& Vismara, 2017). For instance, scholars could investigate the multiple reference points in performance appraisals that family firms use (Chua, Chrisman, \& De Massis, 2015) when women are present in the family business in leadership roles or immediately after a succession.

A fourth research gap entails the mutual relationship between family relations and women's involvement in family firms. Further research could focus on the family level (e.g. James, Jennings, \& Breitkreuz, 2012) to investigate, for example, how family cohesion and conflicts may affect and/or be affected by women's involvement in family firms. Leveraging exchange theories, such as social exchange theory (Kelley \& Thibaut, 1978; Stephen, 1984), 
future research could look at the effects of women's involvement in family firms on the type of social exchange, either generalized or restricted, characterizing family firms. Although generalized social exchange in family firms relates to greater cohesion (Long \& Mathews, 2011), we do not know if family cohesion drives women's involvement in family firms. Indeed, the type of social exchange can affect whether task cohesion or social cohesion characterizes family relations (Pieper, 2010), with potential effects on women's involvement in family firms. Considering the outcomes of women's involvement in family firms through this theoretical lens, future research could investigate its effect on conflicts. A further opportunity for future research lies in exploring the type of conflicts, either affective or cognitive (Eddleston \& Kellermanns, 2007), that characterize family relations due to women's presence or succession in family firms.

The fifth research gap identified looks at the role of family and non-family stakeholders as crucial players affecting and being affected by women's involvement in family firms. Stakeholder theory (Freeman, 1984) offers a lens through which to look at this mutual relationship. In particular, stakeholder salience, which entails powerful, legitimate, and urgent claims, has been conceived as differing in family and non-family firms (Mitchell, Agle, Chrisman, \& Spence, 2011). However, we lack a consistent body of research examining the claims of family vs. non-family members within an organization, and worth studying is whether potentially different claims may affect women's involvement in family firms. Even more interestingly, the family business field may benefit from studies focusing on the outcomes of women's involvement. For example, although there are studies on succession considering the level of personal satisfaction of individuals related to the family business (Sharma, Chrisman, \& Chua, 2003; Sharma, Chrisman, Pablo, \& Chua, 2001), the field may benefit from studies that consider how different types of women's involvement in family firms affect family and non-family stakeholders, not only in terms of satisfaction, but also in terms of commitment 
(e.g. Vallejo, 2009), perceived justice (e.g. Barnett \& Kellermanns, 2006), and trust (e.g. Steier, 2001).

Furthermore, as a sixth research gap, future studies might delve into the individual characteristics of women as antecedents of their involvement in family firms. Despite the different instances emerging from our literature review, theories that discuss the effect of cognitive bases and values, such as upper echelons theory (Hambrick, 2007; Hambrick \& Mason, 1984), may offer interesting lenses to predict the effect of education, previous experience, and functional background on women's involvement in family firms. Nevertheless, we suggest that the outcomes of the different types of women's involvement deserve further attention. Research should investigate whether gender can effectively influence strategic decision-making (e.g. Mustakallio, Autio, \& Zahra, 2002) and leadership style (e.g. Sorenson, 2000), as well as identifying the priorities that women in family business would pursue according to their specific profiles (Cesaroni \& Sentuti, 2014), and implications on their worklife balance and work-family tensions.

Considering the context, further research could investigate women's involvement in family firms across countries, industries, and over time. Indeed, the analysis of political, economic, social, and technological aspects in cross-country studies could illuminate the effect of norms, traditions, and cultural elements on women's involvement in family firms. Leveraging Hofstede's studies $(1991,1998)$ showing the importance of acknowledging cultural dimensions, such as collectivism vs. individualism, power distance and masculinity, scholars could offer insights on the drivers of women's involvement in family firms across different geographic settings. This is in line with the literature stream on women entrepreneurship discussing the effect of country-level dimensions affecting the propensity of women to start their own ventures (e.g. De Bruin, Brush, \& Welter, 2007; Estrin \& Mickiewicz, 2011; Klyver, Nielsen, \& Evald, 2013; Yousafzai, Saeed, \& Muffatto, 2015). Furthermore, future research 
could also consider the differences among families that may shape family business goals, behaviors, and outcomes (Aldrich \& Cliff, 2003; Dyer, 2006). The integration of prevalent family differences in conceptual and empirical studies in the context of family firms is still in its infancy (Powell et al., 2017). One reason for this is that many scholars commonly apply management theories that do not include either the family or its heterogeneity as an element. We encourage future scholars to draw on the "family science" discipline (Jaskiewicz, Combs, Shanine, \& Kacmar, 2017; Jaskiewicz \& Dyer, 2017) to more thoroughly take into account how family aspects (e.g. family-member relationships, family structures, and family events) may affect women's involvement in family firms. Future research should consider family heterogeneity and the variety of family patterns within and across societies around the world (e.g. Morioka, 1967) to understand how differences among families may shape women's involvement in family firms.

Last, given the scarce attention to the chrono-context, a focus on the temporal dimensions may be especially relevant for this research stream in the footsteps of those contributions that look at the phenomena by comparing multiple long-lived firms or studying one firm over generations (Sharma et al., 2014). Future research could investigate the life-courses that have evolved in family and business systems via longitudinal studies (e.g. Zellweger \& Sieger, 2012; Sharma et al., 2014) and/or a historical approach (e.g. Colli, 2012) to offer novel insights to better grasp the drivers of women's involvement in family firms. Moreover, a focus on the family's temporal evolution would help highlight how changes in family norms and motivations can affect women's involvement in family firms. Family developmental theory (Rodgers, 1964; Rodgers \& White, 1993) and the family business developmental model (Gersick, Davis, Hampton, \& Lansberg, 1997) may also provide useful lenses to look at the evolution of the family system — in terms of family roles, relationships, and tasks, as well as new family definitions (considering divorced and remarried couples or same-sex couples) - 
and its interaction with business and ownership lifecycles. Indeed, considering that the business vision changes while women go through different stages of involvement (Dumas, 1998), it would be particularly insightful to match this evidence with theories that offer a dynamic perspective on family and family business development.

\section{Conclusions}

This study has reviewed the flourishing literature on women's involvement in family firms according to a drivers-behaviors-outcomes framework. It shows the increasing interest and greater focus on the features, relationships, governance issues, and norms that characterize the four types of women's involvement in family firms identified, i.e. entrepreneurial entry, succession, career dynamics, and presence of women in family firms.

The drivers-behaviors-outcomes framework has enabled identifying a number of future research directions calling for further inquiry into the topics that have been overlooked or only marginally discussed in prior literature on women's involvement in family firms. More specifically, we respond to recent calls for future research on gender effects (Gagné et al., 2014), temporal orientations and styles (Sharma et al., 2014), and accordingly encourage scholars interested in understanding the drivers and outcomes of women's involvement in family firms to address this phenomenon and contribute with significant new insights to this relevant research stream.

\section{References}

Adrian, T., \& Diana, T. (2010). Gender disparities in the entrepreneurial field in western Romania, Annals of the University of Oradea, Economic Science Series, 19(2), 330-334.

* Ahrens, J.-P., Landmann, A., \& Woywode, M. (2015). Gender preferences in the CEO successions of family firms: Family characteristics and human capital of the successor, Journal of Family Business Strategy, 6(2), 86-103. 
Aldrich, H.E., \& Cliff, J.E. (2003). The pervasive effects of family on entrepreneurship: Toward a family embeddedness perspective, Journal of Business Venturing, 18(5), 573596.

* Amore, M.D., Garofalo, O., \& Minichilli, A. (2014). Gender interactions within the family firm, Management Science, 60(5), 1083-1097.

* Amran, N.A. (2011). The effect of owner's gender and age to firm performance: A review on Malaysian public listed family businesses, Journal of Global Business and Economics, 2(1), 104-116.

Angus, P.M. (2005). The family governance pyramid: From principles to practice, The Journal of Wealth Management, 8(1), 7-13.

Ardichvili, A., Cardozo, R., \& Ray, S. (2003). A theory of entrepreneurial opportunity identification and development, Journal of Business Venturing, 18(1), 105-123.

* Aronoff, C.E. (1998). Megatrends in family business, Family Business Review, 11(3), 181185.

* Aygören, H., \& Nordqvist, M. (2015). Gender, ethnicity and identity work in the family business, European Journal of International Management, 9(2), 160-178.

Au, K., Chiang, F.F., Birtch, T.A., \& Ding, Z. (2013). Incubating the next generation to venture: The case of a family business in Hong Kong, Asia Pacific Journal of Management, 30(3), 749-767.

Barnett, T., \& Kellermanns, F.W. (2006). Are we family and are we treated as family? Nonfamily employees' perceptions of justice in the family firm, Entrepreneurship Theory and Practice, 30(6), 837-854.

* Barrett, M. (2014). Revisiting women's entrepreneurship: Insights from the family-firm context and radical subjectivist economics, International Journal of Gender and Entrepreneurship, 6(3), 231-254.

* Barrett, M., \& Moores, K. (2009). Spotlights and shadows: Preliminary findings about the experiences of women in family business leadership roles, Journal of Management \& Organization, 15(3), 363-377.

Beach B. (1993). Family Support in Home-Based Family Businesses, Family Business Review, $6(4), 371-379$ 
* Bianco, M., Ciavarella, A., \& Signoretti, R. (2015). Women on corporate boards in Italy: The role of family connections, Corporate Governance (Oxford), 23(2), 129-144.

* Blenkinsopp, J., \& Owens, G. (2010). At the heart of things: The role of the "married" couple in entrepreneurship and family business, International Journal of Entrepreneurial Behaviour and Research, 16(5), 357-369.

* Block, J.H., Fisch, C.O., Lau, J., Obschonka, M., \& Presse, A. (2016). Who prefers working in family firms? An exploratory study of individuals' organizational preferences across 40 countries, Journal of Family Business Strategy, 7(2), 65-74.

Bowman-Upton, N. \& Heck, R.K.Z. (1996). The family dimension of entrepreneurship. In Sexton, D.L. (ed.), The State of the Art of Entrepreneurship. Chicago: Upstart.

Burt, R.S. (1997). The contingent value of social capital, Administrative Science Quarterly, 42(2), 339-365.

Cabrera-Suárez, K., De Saá-Pérez, P., \& García-Almeida, D. (2001). The succession process from a resource-and knowledge-based view of the family firm, Family Business Review, 14(1), 37-46.

* Cadieux L., Lorrai J., \& Hugron, P. (2002). Succession in women-owned family businesses: A case study, Family Business Review, 15(1), 17-30.

Carney, M. (2005). Corporate governance and competitive advantage in family-controlled firms, Entrepreneurship Theory and Practice, 29(3), 249-265.

Cesaroni, F.M, \& Sentuti, A. (2014). Women and family businesses. When women are left only minor roles, The History of the Family, 19(3), 358-379.

Chrisman, J.J., Chua, J.H., \& Sharma, P. (1998). Important attributes of successors in family businesses: An exploratory study, Family Business Review, 11(1), 19-34.

Chrisman, J.J., Chua, J.H., Pearson, A.W., \& Barnett, T. (2012). Family involvement, family influence, and family-centered non-economic goals in small firms, Entrepreneurship Theory and Practice, 36(2), 267-293.

Chrisman, J.J., Kellermanns, F.W., Chan, K.C., \& Liano, K. (2010). Intellectual foundations of current research in family business: An identification and review of 25 influential articles, Family Business Review, 23(1), 9-26. 
Chrisman, J.J., \& Patel, P.C. (2012). Variations in R\&D investments of family and nonfamily firms: Behavioral agency and myopic loss aversion perspectives, Academy of Management Journal, 55(4), 76-997.

Chrisman, J.J., Sharma, P., Steier, L.P., \& Chua, J.H. (2013). The influence of family goals, governance, and resources on firm outcomes, Entrepreneurship Theory and Practice, 37, 1249-1261.

Chua, J.H., Chrisman, J.J., \& De Massis, A. (2015). A closer look at socioemotional wealth: Its flows, stocks, and prospects for moving forward, Entrepreneurship Theory and Practice, 39(2), 173-182.

Chua, J. H., Chrisman, J. J., \& Sharma, P. (1999). Defining the family business by behavior, Entrepreneurship Theory and Practice, 23(4), 19-39.

Chua, J.H., Chrisman, J.J., Steier, L.P., \& Rau, S.B. (2012). Sources of heterogeneity in family firms: An introduction, Entrepreneurship Theory and Practice, 36(6), 1103-1113.

* Cicellin, M., Mussolino, D., \& Viganò, R (2015). Gender diversity and father-daughter relationships: Understanding the role of paternalistic leadership in family firm succession, International Journal of Business Governance and Ethics, 10(1), 97-118.

* Cole, P.M. (1997). Women in family business, Family Business Review, 10(4), 353-371.

* Cole, P.M., \& Johnson, K. (2007). An exploration of successful copreneurial relationships postdivorce, Family Business Review, 20(3), 185-198.

Colli, A. (2012). Contextualizing performance in family firms: The perspective of business history, Family Business Review, 25(3), 243-257.

* Cruz, C., Justo, R., \& De Castro, J.O. (2012). Does family employment enhance MSEs performance? Integrating socioemotional wealth and family embeddedness perspectives, Journal of Business Venturing, 27(1), 62-76.

* Curimbaba, F. (2002). The Dynamics of Women's roles as family business managers, Family Business Review, 15(3), 239-252.

* Danes, S.M., \& Olson, P.D. (2003). Women's role involvement in family businesses, business tensions, and business success, Family Business Review, 16(1), 53-68. 
Danes, S.M., Stafford, K., Haynes, G., \& Amarapurkar, S.S. (2009). Family capital of family firms: Bridging human, social, and financial capital. Family Business Review, 22(3), 199215.

* Danes, S.M., Stafford, K., \& Loy, J.T. (2007). Family business performance: The effects of gender and management, Journal of Business Research, 60(10), 1058-1069.

* Deacon, J.H., Harris, J.A., \& Worth, L. (2014). Who leads? Fresh insights into roles and responsibilities in a heterosexual copreneurial business, International Journal of Gender and Entrepreneurship, 6(3), 317-335.

De Bruin, A., Brush, C.G., \& Welter, F. (2007). Advancing a framework for coherent research on women's entrepreneurship, Entrepreneurship Theory and Practice, 31(3), 323-339.

De Massis, A., Frattini, F., \& Lichtenthaler, U. (2013). Research on technological innovation in family firms: Present debates and future directions, Family Business Review, 26(1), 1031.

De Massis, A., Sharma, P., Chua, J.H., \& Chrisman, J.J. (2012). Family business studies: An annotated bibliography. Edward Elgar, Cheltenham Glos, UK.

* Dhaliwal, S. (2000). Asian female entrepreneurs and women in business - an exploratory study, Enterprise and Innovation Management Studies, 1(2), 207-216.

Dobrzynski, J. (1993). Relationship investing, Business Week, 3309(15), 68-75.

Dreux IV, D.R. (1990). Financing family business: Alternatives to selling out or going public, Family Business Review, 3(3), 25-243.

* Dumas, C.A. (1990). Preparing the new CEO: Managing the father-daughter succession process in family businesses, Family Business Review, 3(2), 169-181.

* Dumas, C.A. (1992). Integrating the daughter into family business management, Entrepreneurship Theory and Practice, 16(4), 41-55.

* Dumas, C. (1998). Women's pathways to participation and leadership in the family-owned firm, Family Business Review, 11(3), 219-228.

Dyer, W.G. (2006). Examining the family effect on firm performance, Family Business Review, 19(4), 253-273. 
Eddleston, K.A., \& Kellermanns, F.W. (2007). Destructive and productive family relationships: A stewardship theory perspective, Journal of Business Venturing, 22(4), 545-565.

Ernst and Young (2015). Women in leadership http://www.ey.com/Publication/vwLUAssets/ey-women-in-leadership-the-familybusiness-advantage/\$FILE/ey-women-in-leadership-the-family-business-advantage.pdf

Estrin, S., \& Mickiewicz, T. (2011). Institutions and female entrepreneurship, Small Business Economics, 37(4), 397-415.

Fairlie, R.W. (2005). Entrepreneurship and earnings among young adults from disadvantaged families, Small Business Economics, 25(3), 223-236.

* Farrington, S.M., Venter, E., Eybers, C., \& Boshoff, C. (2011). Structuring effective copreneurial teams, South African Journal of Business Management, 42(3), 1-15.

Federal Glass Ceiling Commission. Solid Investments. (1995). Making full use of the nation's human capital. Washington, D.C. - U.S. Department of Labor, p. 4 https://www.dol.gov/oasam/programs/history/reich/reports/ceiling2.pdf.

Feliu, N. \& Botero, I. (2016). Philanthropy in family enterprises: A review of literature, Family Business Review, 29, 121-141.

* Fletcher, D. (2010). Life-making or risk taking? Copreneurship and family business startups, International Small Business Journal, 28(5), 452-469.

Fletcher, D., De Massis, A., \& Nordqvist, M. (2016). Qualitative research practices and family business scholarship: A review and future research agenda, Journal of Family Business Strategy, 7(1), 8-25.

Forbes. (2015). The effect of female executives: positive for family firms, negative for public ones $\quad$ http://www.forbes.com/sites/timworstall/2015/12/07/the-effect-of-female$\underline{\text { executives-positive-for-family-firms-negative-for-public-ones/\#6cf5f23016db }}$

Freeman, R.E. (1984). Strategic management: A stakeholder approach, Cambridge University Press.

* Frishkoff, P.A., \& Brown, B.M. (1993). Women on the move in family business, Business Horizons, 36(2), 66-70. 
Furrer, O., Thomas, H., \& Goussevskaia, A. (2008). The structure and evolution of the strategic management field: A content analysis of 26 years of strategic management research, International Journal of Management Reviews, 10(1), 1-23.

Gagné, M., Sharma, P., \& De Massis, A. (2014). The study of organizational behaviour in family business, European Journal of Work and Organizational Psychology, 23(5), 643656.

* Galbraith, C.S. (2003). Divorce and the financial performance of small family businesses: An exploratory study, Journal of Small Business Management, 41(3), 296-309.

* Galiano, A.M., \& Vinturella J.B. (1995). Implications of gender bias in the family business, Family Business Review, 8(3), 177-188.

Gersick, K.E., Davis J.A., Hampton M.M., \& Lansberg I. (1997). Generation to generation: Life cycles of the family business, Boston: Harvard Business School Press.

* Gherardi, S. (2015). Authoring the female entrepreneur while talking the discourse of workfamily life balance, International Small Business Journal, 33(6), 649-666.

* Gherardi, S., \& Perrotta, M. (2016). Daughters taking over the family business: Their justification work within a dual regime of engagement, International Journal of Gender and Entrepreneurship, 8(1), 28-47.

* Gillis-Donovan, J., \& Moynihan-Bradt, C. (1990). The power of invisible women in the family business, Family Business Review, 3(2), 153-167.

* Glover, J.L. (2014). Gender, power and succession in family farm business, International Journal of Gender and Entrepreneurship, 6(3), 276-295.

Gómez-Mejía, L.R., Haynes, K.T., Núñez-Nickel, M., Jacobson, K.J., \& Moyano-Fuentes, J. (2007). Socioemotional wealth and business risks in family-controlled firms: Evidence from Spanish olive oil mills, Administrative Science Quarterly, 52(1), 106-137.

Grant, R. (1991). Contemporary strategy analysis, Blackwell Publishing Ltd.

* Gundry, L.K., \& Ben-Yoseph, M. (1998). Women entrepreneurs in Romania, Poland, and the United States: Cultural and family influences on strategy and growth, Family Business Review, 11(1), 61-73. 
Gupta, V. and Levenburg, N.M. (2013). Women in family business: three generations of research, in Smyrnios, K.X., Poutziouris, P.Z., Goel, S. (Eds.) Handbook of Research on Family Business, Second Edition, Celthenham, US: Edward Elgar Publishing Limited.

Habbershon, T.G., \& Williams, M.L. (1999). A resource-based framework for assessing the strategic advantages of family firms, Family Business Review, 12(1), 1-25.

Habbershon, T.G., Williams, M., \& MacMillan, I.C. (2003). A unified systems perspective of family firm performance. Journal of Business Venturing, 18(4), 451-465.

* Haberman, H., \& Danes, S.M. (2007). Father-daughter and father-son family business management transfer comparison: Family FIRO model application, Family Business Review, 20(2), 163-184.

Hambrick, D.C. (2007). Upper echelons theory: An update, Academy of Management Review, 32(2), 334-343.

Hambrick, D.C., \& Mason P.A. (1984). Upper echelons: The organization as a reflection of its top managers, Academy of Management Review, 9(2), 193-206.

* Hamilton, E. (2006). Whose story is it anyway? Narrative accounts of the role of women in founding and establishing family businesses, International Small Business Journal, 24(3), 253-271.

* Harveston, P.D., Davis, P.S., \& Lyden, J.A. (1997). Succession planning in family business: The impact of owner gender, Family Business Review, 10(4), 373-396.

Haynes, G.W., Walker, R., Rowe, B.R., \& Hong, G.S. (1999). The intermingling of business and family finances in family-owned businesses, Family Business Review, 12(3), 225-239.

* Hedberg, P.R., \& Danes, S.M. (2012). Explorations of dynamic power processes within copreneurial couples, Journal of Family Business Strategy, 3(4), 228-238.

* Heinonen, J., \& Stenholm, P. (2011). The contribution of women in family business, International Journal of Entrepreneurship and Innovation Management, 13(1), 62-79.

* Hisrich, R.D. \& Fülöp, G. (1997). Women entrepreneurs in family business: The Hungarian case, Family Business Review, 10(3), 281-302.

* Hoffmann, A., Junge, M., \& Malchow-Møller, N. (2015). Running in the family: Parental role models in entrepreneurship, Small Business Economics, 44(1), 79-104. 
Hofstede, G. (1991). Cultures and organizations: Software of the mind, London, UK: McGrawHill.

Hofstede, G. (1998). Attitudes, values and organizational culture: Disentangling the concepts, Organization Studies, 19(3), 477-493.

* Hollander, B.S., \& Bukowitz, W.R. (1990). Women, family culture, and family business, Family Business Review, 3(2), 139-151.

Horton, T.P. (1986). Managing in a family way, Management Review, 75(2), 3.

* Howorth, C., Rose, M., Hamilton, E., \& Westhead, P. (2010). Family firm diversity and development: An introduction, International Small Business Journal, 28(5), 437-451.

Huse, M. (2007). Boards, governance and value creation: The human side of corporate governance, Cambridge: Cambridge University Press.

James, A.E., Jennings, J.E., \& Breitkreuz, R.S. (2012). Worlds apart? Rebridging the distance between family science and family business research, Family Business Review, 25(1), 87108.

Jaskiewicz, P., Combs, J., Shanine, K., \& Kacmar, M. (2017). Introducing the family: A review of family science with implications for management, Academy of Management Annals, 11(1), 309-341.

Jaskiewicz, P., \& Dyer, W.G. (2017). Addressing the Elephant in the Room: Dis-entangling Family Heterogeneity to Advance Family Business Research, Family Business Review, 30(2), 111-118.

* Jimenez, R.M. (2009). Research on women in family firms: Current status and future directions, Family Business Review, 22(1), 53-64.

* Karatas-Özkan, M., Erdogan, A., \& Nicolopoulou, K. (2011). Women in Turkish family businesses: Drivers, contributions and challenges, International Journal of Cross Cultural Management, 11(2), 203-219.

* Kaslow, F.W. (1998). Handling transitions from mother to son in the family business: The knotty issues, Family Business Review, 11(3), 229-238.

Kelley, H.H., \& Thibaut, J.W. (1978). Interpersonal relationships. A theory of Interdependence, New York: John Wiley \& Sons. 
* Kickul, J., Jianwen (Jon) L., Gundry, L., \& Iakovleva, T. (2010). Firm resources, opportunity recognition, entrepreneurial orientation and performance: The case of Russian women-led family businesses, International Journal of Entrepreneurship and Innovation Management, 12(1), 52-69.

* Kilkolly-Proffit, M. (2013). Socialisation of daughters in women-led family businesses, University of Auckland Business Review, 16(1), 6-15.

Klyver, K., Nielsen, S.L., \& Evald, M.R. (2013). Women's self-employment: An act of institutional (dis) integration? A multilevel, cross-country study, Journal of Business Venturing, 28(4), 474-488.

* Koffi, V., Guihur, I., Morris, T., \& Fillion, G. (2014). Family business succession: How men and women predecessors can bring credibility to their successors? Entrepreneurial Executive, 19, 67-85.

Kotlar, J., \& De Massis, A. (2013). Goal setting in family firms: Goal diversity, social interactions, and collective commitment to family-centered goals, Entrepreneurship Theory and Practice, 37(6), 1263-1288.

Kotlar, J., Signori, A., De Massis, A., \& Vismara, S. (2017). Financial wealth, socioemotional wealth and IPO underpricing in family firms: A two-stage gamble model, Academy of Management Journal. In press. DOI: 10.5465/amj.2016.0256.

* Kuschel, K., \& Lepeley, M.-T. (2016). Copreneurial women in start-ups: Growth-oriented or lifestyle? An aid for technology industry investors [Mujeres coemprendedoras en startups: ¿Crecimiento del negocio o estilo de vida? Apoyo a inversionistas en la industria tecnológica], Academia, 29(2), 181-197.

* Lakshmi Bala, M., Kavitha, J., \& Suresh Kumar, V. (2016). Conceptual model fit for women entrepreneurs' satisfaction towards their business by using structural equation model, Indian Journal of Science and Technology, 9(44), 1-9.

* Lerner, M., \& Malach-Pines, A. (2011). Gender and culture in family business: A ten-nation study, International Journal of Cross Cultural Management, 11(2), 113-131.

Long, R.G., \& Mathews, K.M. (2011). Ethics in the family firm: Cohesion through reciprocity and exchange, Business Ethics Quarterly, 21(2), 287-308.

Lumpkin, G.T., Steier, L., \& Wright, M. (2011). Strategic entrepreneurship in family business, Strategic Entrepreneurship Journal, 5(4), 285-306. 
* Lussier, R.N., \& Sonfield, M.C. (2007). A comparison of family-member and non-familymember managers in American family businesses, Academy of Entrepreneurship Journal, 13(2), 31-46.

* Lyman, A.R. (1988). Life in the family circle, Family Business Review, 1(4), 383-398.

* Lyman, A., Salganicoff, M., \& Hollander, B. (1985). Women in family business - an untapped resource, SAM Advanced Management Journal, 50(1), 46-49.

Marchisio, G., Mazzola, P., Sciascia, S., Miles, M., \& Astrachan, J. (2010). Corporate venturing in family business: The effects on the family and its members, Entrepreneurship and Regional Development, 22(3-4), 349-377.

* Marshack, K.J. (1993). Coentrepreneurial couples: A literature review on boundaries and transitions among copreneurs, Family Business Review, 6(4), 355-369.

* Marshack, K.J. (1994). Copreneurs and dual-career couples: Are they different? Entrepreneurship Theory and Practice, 19(1), 49-69.

* Mathew, V. (2016). Women and family business succession in Asia - characteristics, challenges and chauvinism, International Journal of Entrepreneurship and Small Business, 27(2-3), 410-424.

* Merono-Cerdan, A.L., \& López-Nicolás, C. (2017). Women in management: Are family firms somehow special? Journal of Management \& Organization, 23(2), 224-240.

Millman, C., \& Martin, L.M. (2007). Exploring small copreneurial food companies: Female leadership perspectives, Women in Management Review, 22(3), 232-239.

* Mínguez-Vera, A., \& Martin, A. (2011). Gender and management on Spanish SMEs: An empirical analysis, International Journal of Human Resource Management, 22(14), 28522873.

Minichilli, A., Corbetta, G. and MacMillan, I.C. (2010). Top Management Teams in FamilyControlled Companies: 'Familiness', 'Faultlines', and Their Impact on Financial Performance, Journal of Management Studies, 47(2), 205-222.

Mitchell, R.K., Agle, B.R., Chrisman, J.J., \& Spence, L.J. (2011). Toward a theory of stakeholder salience in family firms, Business Ethics Quarterly, 21(02), 235-255.

Morioka K. (1967). Life cycle patterns in Japan, China, and the United States, Journal of Marriage and the Family, 29(3), 595-606. 
Mustakallio, M., Autio, E., \& Zahra, S.A. (2002). Relational and contractual governance in family firms: Effects on strategic decision making, Family Business Review, 15(3), 205222.

* Nelton, S. (1998). The rise of women in family firms: A call for research now, Family Business Review, 11(3), 215-218.

* Nikina, A., Shelton, L.M., Leloarne, S. (2015). An examination of how husbands, as key stakeholders, impact the success of women entrepreneurs, Journal of Small Business and Enterprise Development, 22(1), 38-62.

* O’Connor, V., Hamouda, A., McKeon, H., Henry, C., \& Johnston, K. (2006). Coentrepreneurial ventures. A study of mixed gender founders of ICT companies in Ireland, Journal of Small Business and Enterprise Development, 13(4), 600-619.

Ordanini, A., Rubera, G., \& DeFillippi, R. (2008). The many moods of inter-organizational imitation: A critical review, International Journal of Management Reviews, 10(4), 375398.

* Overbeke, K.K., Bilimoria, D., \& Perelli, S. (2013). The dearth of daughter successors in family businesses: Gendered norms, blindness to possibility, and invisibility, Journal of Family Business Strategy, 4(3), 201-212.

* Peake, W.O., Cooper, D., Fitzgerald, M.A., \& Muske, G. (2015). Family business participation in community social responsibility: The moderating effect of gender, Journal of Business Ethics, doi: 10.1007/s10551-015-2716-z pp 1-19.

Pearson, A.W., Carr, J.C., \& Shaw, J.C. (2008). Toward a theory of familiness: A social capital perspective, Entrepreneurship Theory and Practice, 32(6), 949-969.

Pierce, J.L., Kostova, T., \& Dirks, K.T. (2003). The state of psychological ownership: integrating and extending a century of research, Review of General Psychology, 7, 84-107.

Pieper, T.M. (2010). Non solus: Toward a psychology of family business, Journal of Family Business Strategy, 1(1), 26-39.

Podsakoff, P., MacKenzie, S., Bachrach, D., \& Podsakoff, N. (2005). The influence of management journals in the 1980s and 1990s, Strategic Management Journal, 26, 473488. 
Powell, G.N., Greenhaus, J.H. Jaskiewicz, P., Combs, J.G., Balkin, D.B., \& Shanine, K.K. (2017). Family science and the work-family interface: An interview with Gary Powell and Jeffrey Greenhaus, Human Resource Management Review, forthcoming.

PricewaterhouseCoopers (2016). PwC Next Generation Survey 2016: The Female Perspective.http://www.pwc.com/gx/en/family-businessservices/assets/Next_Generation_Survey_\%20Female_Perspective_Final.pdf

* Robinson, S., \& Stubberud, H.A. (2012). All in the family: Entrepreneurship as a family tradition, International Journal of Entrepreneurship, 16, 19-30.

Rodgers, R.H. (1964). Toward a theory of family development, Journal of Marriage and the Family, 26(3), 262-270.

Rodgers, R.H, \& White, J.M. (1993). Family development theory. In Boss P, Doherty WJ, LaRossa R, Schumm WR, Steinmetz SK (eds.), Sourcebook of Family Theories and Methods, New York: Springer.

* Rodríguez-Ariza, L., Cuadrado-Ballesteros, B., Martínez-Ferrero, J., \& García-Sanchez, I.M. (2017). The role of female directors in promoting CSR practices: An international comparison between family and non-family businesses, Business Ethics - A European Review, 26(2), 162-174, doi 10.1111/beer.12140.

* Rothausen, T.J. (2009). Management work-family research and work-family fit: Implications for building family capital in family business, Family Business Review, 22(3), 220-234.

* Rowe, B.R., \& Hong, G.S. (2000). The role of wives in family businesses: The paid and unpaid work of women, Family Business Review, 13(1), 1-13.

* Salganicoff, M. (1990). Women in family businesses: Challenges and opportunities, Family Business Review, 3(2), 125-137.

* Schröder, E., Schmitt-Rodermund, E., \& Arnaud, N. (2011). Career choice intentions of adolescents with a family business background, Family Business Review, 24(4), 305-321.

Sharma, P. (2008). Commentary: Familiness: Capital stocks and flows between family and business, Entrepreneurship Theory and Practice, 32(6), 971-977.

Sharma, P., \& Chrisman, J.J. (1999). Toward a reconciliation of the definitional issues in the field of corporate entrepreneurship, Entrepreneurship Theory and Practice, 23(3), 11-27. 
Sharma, P., Chrisman, J.J., \& Chua, J.H. (2003). Predictors of satisfaction with the succession process in family firms, Journal of Business Venturing, 18(5), 667-687.

Sharma, P., Chrisman, J.J., Pablo, A.L., \& Chua, J.H. (2001). Determinants of initial satisfaction with the succession process in family firms: A conceptual model, Entrepreneurship Theory and Practice, 25(3), 17-36.

Sharma, P., Chua, J.H., \& Chrisman, J.J. (2000). Perceptions about the extent of succession planning in Canadian family firms, Canadian Journal of Administrative Sciences / Revue Canadienne des Sciences de l'Administration, 17(3), 233-244.

Sharma, P., Salvato, C., \& Reay, T. (2014). Temporal dimensions of family enterprise research, Family Business Review, 27(1), 10-19.

* Singh, V., Point, S., Moulin, Y., \& Davila, A. (2015). Legitimacy profiles of women directors on top French company boards, Journal of Management Development, 34(7), 803-820.

Sirmon, D.G., \& Hitt, M.A. (2003). Managing resources: Linking unique resources, management, and wealth creation in family firms, Entrepreneurship Theory and Practice, 27(4), 339-358.

* Smith, G.D. (2009). East Africa: Extended families with many rights, Entrepreneurship Theory and Practice, 33(6), 1239-1244.

* Smith, R. (2014). Assessing the contribution of the 'theory of matriarchy' to the entrepreneurship and family business literatures, International Journal of Gender and Entrepreneurship, 6(3), 255-275.

* Smythe, J., \& Sardeshmukh, S.R. (2013). Fathers and daughters in family business, Small Enterprise Research, 20(2), 98-109.

* Songini, L., \& Gnan, L. (2009). Women, glass ceiling, and professionalization in family SMEs: a missed link, Journal of Enterprising Culture, 17(4), 497-525.

Sorenson, R.L. (2000). The contribution of leadership style and practices to family and business success, Family Business Review, 13(3), 183-200.

Steier, L. (2001). Family firms, plural forms of governance, and the evolving role of trust, Family Business Review, 14(4), 353-368.

Stephen, T. (1984). A symbolic exchange framework for the development of intimate relationships, Human Relations, 37(5), 393-408. 
* Sundarasen, S.D.D., Je-Yen, T., \& Rajangam, N. (2016). Board composition and corporate social responsibility in an emerging market, Corporate Governance, 16(1), 35-53.

* Vadnjal, J., \& Zupan, B. (2011). Family business as a career opportunity for women, South East European Journal of Economics and Business, 6(2), 27-36.

Vallejo, M.C. (2009). The effects of commitment of non-family employees of family firms from the perspective of stewardship theory, Journal of Business Ethics, 87(3), 379-390.

* Van Auken, H., \& Werbel, J. (2006). Family dynamic and family business financial performance: Spousal commitment, Family Business Review, 19(1), 49-63.

* Vandebeek, A., Voordeckers, W., Lambrechts, F., \& Huybrechts, J. (2016). Board role performance and faultlines in family firms: The moderating role of formal board evaluation, Journal of Family Business Strategy, 7(4), 249-259.

* Van den Berghe, L.A.A., \& Carchon, S. (2003). Agency relations within the family business system: An exploratory approach, Corporate Governance: An International Review, 11(3), 171-179.

* Van der Merwe, S.P. (2009). Determinants of family employee work performance and compensation in family businesses, South African Journal of Business Management, $40(1), 51-63$.

* Vera, C.F., \& Dean, M.A. (2005). An examination of the challenges daughters face in family business succession, Family Business Review, 18(4), 321-345.

* Welsh, D.H.B., Memili, E., Kaciak, E., \& Ahmed, S. (2013). Sudanese women entrepreneurs, Journal of Developmental Entrepreneurship, 18(2), 1350013 (18 pages).

*Welsh, D.H.B., Memili, E., Kaciak, E., \& Al Sadoon, A. (2014). Saudi women entrepreneurs: A growing economic segment, Journal of Business Research, 67(5), 758-762.

* Welsh, D.H.B., Memili, E., Kaciak, E., \& Ochi, M. (2014). Japanese women entrepreneurs: Implications for family firms, Journal of Small Business Management, 52(2), 286-305.

Wright, M., Chrisman, J.J., Chua, J.H., \& Steier, L.P. (2014). Family enterprise and context. Entrepreneurship Theory and Practice, 38(6), 1247-1260.

* Wu, M., Chang, C., \& Zhuang, W. (2010). Relationships of work-family conflict with business and marriage outcomes in Taiwanese copreneurial women, International Journal of Human Resource Management, 21(5), 742-753. 
Yousafzai, S.Y., Saeed, S., \& Muffatto, M. (2015). Institutional theory and contextual embeddedness of women's entrepreneurial leadership: Evidence from 92 countries, Journal of Small Business Management, 53(3), 587-604.

* Zapalska, A.M., Bugaj, M.N., \& Rudd, D. (2005). Female entrepreneurship in transition Polish economy, Problems and Perspectives in Management, 3(2), 32-39.

Zellweger, T., \& Sieger, P. (2012). Entrepreneurial orientation in long-lived family firms, Small Business Economics, 38(1), 67-84. 